\title{
Corneal Dermoid in Two Laboratory Beagle Dogs
}

\author{
Kazuya HORIKIRI, Kiyokazu OZAKI, Hiroshi MAEDA, and Isao NARAMA \\ Research Institute of Drug Safety, Setsunan University, 45-1 Nagaotoge-cho, \\ Hirakata-shi, Osaka 573-01, Japan
}

(Received 21 December 1993 / Accepted 2 February 1994)

\begin{abstract}
Two male laboratory beagle dogs used in toxicity studies, one 7 months old and the other 9 months old, showed the evidence of corneal dermoid. Grossly, the dermoid was observed in both cases as hair growth from the cornea. In one case, the hairs had been removed from the cornea, but regrowth was observed about 70 days later. Histopathologically, melanocytes, melanin granules, hairs, hair bulbs, adipose tissue and sebaceous and sweat glands were observed in the corneal epithelium and propria. According to the information obtained from 4 breeders, the incidence of corneal dermoid was extremely rare in laboratory beagle dogs.—KEY WORDS : beagle dog, cornea, dermoid
\end{abstract}

Corneal dermoid is a congenital choristoma characterized by the presence of heterotopic cutaneous tissue in the cornea, bulbar conjunctiva or both $[2,7-9,11]$. This condition is known to occur in cattle $[5,7,9,11,12]$, horses $[8,9]$, sheep $[3,9]$, large breed dogs such as St. Bernards $[1,4-6,12]$ and German Shepherds [4] and short-legged dogs [12] such as Basset Hounds, Dachshunds and Welsh Corgis, but it has not been reported in laboratory beagle dogs. This paper describes detailed histopathological findings and the incidence of corneal dermoid in laboratory beagle dogs.

The present cases involve two male beagle dogs, one 7 months old and the other 9 months old, purchased from a breeder in Japan for toxicity studies carried out in our laboratory from January 1991 to October 1992.

In the first case, a pale brown region measuring 5-7 mm in diameter was noted grossly at the junction of the cornea and bulbar conjunctiva at the 9 o'clock corner of the right eye. The surface of this region was rough and slightly elevated above the surrounding normal cornea. Three randomly-oriented hairs were found growing out of this region (Fig. 1). These hairs were removed with forceps during the quarantine period, because this lesion was thought to be a scar with traumatic implanta- tion of hairs. However, regrowth of the hairs was observed about 70 days after the removal.

In the second case, a region of the same color, measuring $3-5 \mathrm{~mm}$ in diameter, was observed in the limbus at the 3 o'clock corner of the right eye. Two hairs were found growing out of this area. Signs of ocular irritation such as blinking and epiphora were not present in either dog, and the left eye was normal in both cases.

Since the arrival in our laboratory, these dogs had been housed as usual, individually in stainless cages in an airconditional animal room, and given $300 \mathrm{~g} /$ day of cubed laboratory chow (Oriental Yeast Co., Ltd.) and tap water ad libitum.

The dogs were euthanatized by exsanguination following the injection of sodium pentobarbital at a dose of $25 \mathrm{mg} / \mathrm{kg}$. The eyes were removed and fixed in Davidson's solution, automatically processed and embedded in paraffin. Sections were cut at $5 \mu \mathrm{m}$ and stained with hematoxylin and eosin (HE).

Histopathologically, the lesions were observed as cutaneous tissue mingled with the normal structure of the corneal epithelium and propria. Namely, the normal corneal epithelium consisted of 2-3 layers of columnar cells on the basal side and 3-4 overlying layers of 
squamous cells without keratohyaline granules and having indistinct intercellular bridges. In the dermoid region, the corneal epithelium was composed of a single layer of basal columnar cells and 3-4 layers of elliptic or slightly flattened cells with distinct intercellular bridges. Melanocytes with long dendritic projections were often observed in the basal layer (Fig. 2) . A small number of melanin granules were also observed in the epithelial cells of the basal and prickle cell layers. The epitheliumpropria junction was irregular.

In the normal substantia propria, collagen bundles were arranged parallel to the corneal surface and formed a dense lamella. On the other hand, they were irregularly oriented and many capillary vessels were formed in the dermoid lesion. Hair and skin appendage tissue consisting of hair bulbs in the resting stage, sebaceous glands opening into the infundibulum and sweat glands were observed in the dermoid (Fig. 3). Adipose tissue corresponding to subcutaneous fat tissue was found at the bottom of the region.

Corneal dermoid has been reported in various species of animals and in humans, and it is commonly believed that this disease is generally congenital, although not hereditary. However, some reported cases are believed to be linked to genetic factors, because of the high frequency of corneal dermoid which occurred in one band of sheep [3]. Several authors have also noted a higher occurrence of corneal dermoid in St. Bernards than in other breeds of dogs $[1,4-6,12]$. In humans, the appearance of corneal dermoid across three generations of a single family has been reported by Mattos and his colleagues $[10]$.

Our experience of two cases of corneal dermoid in about a two-year period might suggest a relatively high incidence in experimental beagle dogs. Accordingto the informa- tion obtained from the four breeders supplying laboratory beagle dogs used in our laboratory, the incidence of corneal dermoid was $0.002 \%$ over fourteen years, $0.03 \%$ over fourteen years, $0.015 \%$ over five years and $0.006 \%$ over six years, respectively. However, no other affected animals were detected in the colony of beagle dogs from which the two present cases were derived, including the other several offsprings from the same parent animals. Therefore, the reason for the occurrence of two cases of corneal dermoid in a relatively short period in one colony remains unclear. Other factors that might have an effect on the normal development of corneal tissue and opening of the eyes such as perinatal infection and local growth retardation must be considered to be the pathogenesis of the present cases.

\section{References}

[1] Burns, M. and Fraser, M. N. (1966). In Genetics of the Dog, pp. 91, J. P. Lippincott Company, Philadelphia.

[2] Carlton, W. W. and Render, J. A. (1988). In Special Veterinary Pathology, pp. 572, Thomson R. G. (ed.), B. C. Decker. Inc., Toronto.

[3] Davis, C. L. (1934). J. A. V. M. Ass ., 85, 679-682.

[4] Gelatt, K. N. (1971). Vet. Med. Small Anim. Clin., 66, 658-659.

[5] Gelatt, K. N. (1972). Vet. Med. Small Anim. Clin., 67, 1217 .

[6] Gelatt, K. N. (1973). Vet. Clin. North Am., 3, 321 -333 .

[ 7 ] Jones, T. C. and Hunt, R. D. (1979). In Veterinary Pathology, pp. 1692-1695, Lea \& Febiger, Philadelphia.

[8] Latimer, C. A. and Wyman, M. (1985). Vet. Clin. North Am. Equine Pract., 1, 235-259.

[9] Lawson, D. D. (1975). Vet. Rec., 97, 449-450.

[10] Mattos, J., Contreras, F., and O'Donnell, F. E. (1980). Arch. Ophthalmol., 98, 1059-1061.

[11] Neumann, S. M. (1984). Mod. Vet. Pract., 65, 553 -554 .

[12] Priester, W. A. (1972).J.A.V.M.A., 160, 1504 -1511 . 


\title{
実験用ビーグル犬にみられた角膜 Dermoid の 2 例
}

\author{
堀切和哉・尾崎清和 - 前田博 - 奈良間 功
}

攝南大学薬物安全科学研究所

毒性試験に用いた実験用ビーグル犬のなかで生後

7 力月秢および 9 力月粭の 2 例の雄性ビーグル犬に 角膜 Dermoid がみられた。肉眼的には角膜からの発 毛が観察された。1例については, 角膜から毛を抜去 したにもかかわらず, 約70日後には再び発毛が観察さ
れた。病理組織学的検查では, メラノサイト,メラニ ン顆粒, 毛, 毛包, 脂肪織, 皮脂腺および汗腺が角膜 上皮と固有質に認められた。実験用ビーグル犬の場 合, 角膜 Dermoid の発現率は非常に低いことが 4 力 所の生産業者からの情報により確認できた。

\section{Explanation of Figures}

Fig. 1. Gross appearance of corneal dermoid. Focal pigmentation of the cornea with hair growth in the right eye of a 7-month-old male laboratory beagle dog.

Fig. 2. Histological appearance of corneal dermoid. Melanocytes and melanin granules in the partially epidermis-like epithelial layer with irregularly oriented underlying collagen bundles (H\&E, $\times$ 300 ).

Fig. 3. Histological appearance of corneal dermoid. Blood vessels, a hair shaft, a hair bulb in the resting stage, and sebaceous and sweat glands in the corneal propria $(\mathrm{H} \& \mathrm{E}, \times 80)$. 


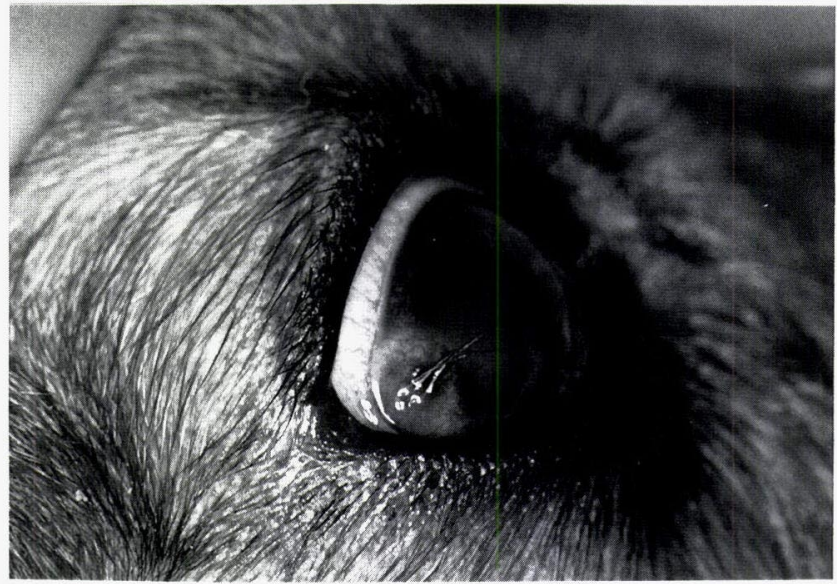

Fig. 1.

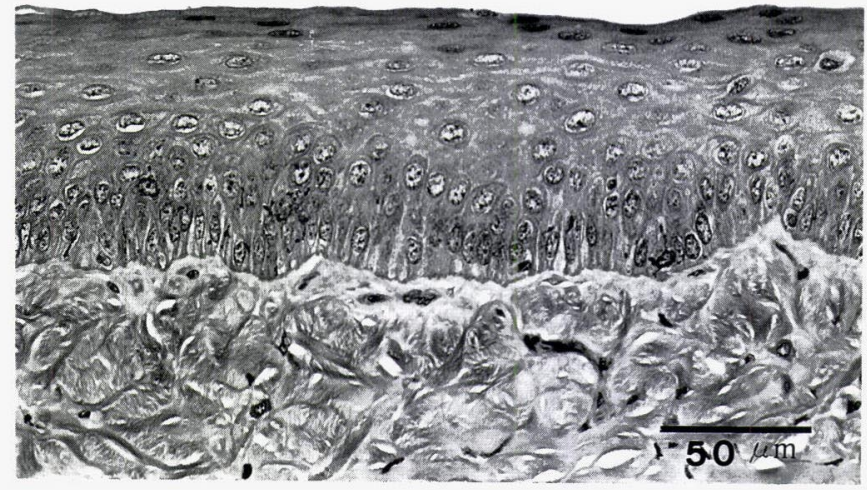

Fig. 2.

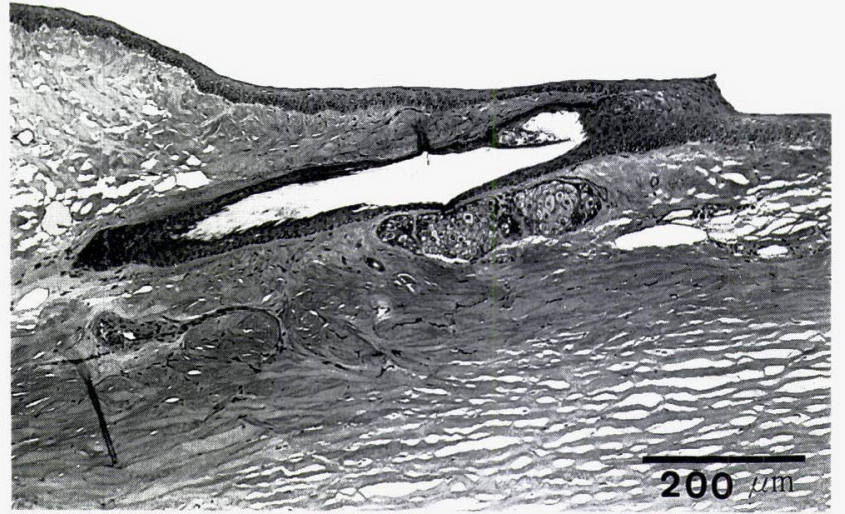

Fig. 3 . 